\title{
"Behandelen is niet genoeg ....."
}

Citation for published version (APA):

Janknegt, R. A. (1988). "Behandelen is niet genoeg .....". Rijksuniversiteit Limburg. https://doi.org/10.26481/spe.19880415rj

Document status and date:

Published: 15/04/1988

DOI:

10.26481/spe.19880415rj

Document Version:

Publisher's PDF, also known as Version of record

\section{Please check the document version of this publication:}

- A submitted manuscript is the version of the article upon submission and before peer-review. There can be important differences between the submitted version and the official published version of record.

People interested in the research are advised to contact the author for the final version of the publication, or visit the DOI to the publisher's website.

- The final author version and the galley proof are versions of the publication after peer review.

- The final published version features the final layout of the paper including the volume, issue and page numbers.

Link to publication

\footnotetext{
General rights rights.

- You may freely distribute the URL identifying the publication in the public portal. please follow below link for the End User Agreement:

www.umlib.nl/taverne-license

Take down policy

If you believe that this document breaches copyright please contact us at:

repository@maastrichtuniversity.nl

providing details and we will investigate your claim.
}

Copyright and moral rights for the publications made accessible in the public portal are retained by the authors and/or other copyright owners and it is a condition of accessing publications that users recognise and abide by the legal requirements associated with these

- Users may download and print one copy of any publication from the public portal for the purpose of private study or research.

- You may not further distribute the material or use it for any profit-making activity or commercial gain

If the publication is distributed under the terms of Article $25 \mathrm{fa}$ of the Dutch Copyright Act, indicated by the "Taverne" license above, 
"Behandelen is niet genoeg ....."

Rede uitgesproken bij het alanvaarden van het ambt van

gewoon hoogleraar in de Urologie aan de Rijksuniversiteit Limburg op vrijdag 15 a pril 1988.

Dr. R.A. Janknegt 

"De annloop is altijd groter dan de sprong"

Cornehs Verhoeven 

Met de vervulling van de leerstoel Urologie schaart de Rijksuniversiteit Limburg zich als laatste in de rij van Nederlandse Universiteiten met een dergelijke leerstoel.

In 1964 startte de erkenning van de Urologie in Nederland als een zelfstandig vak. Het werd blijkbaar de moeite waard om naast patientenzorg ook wetenschap te bedrijven en onderwijs te geven. Dit kwam tot uiting door de benoeming van Moonen als eerste hoogleraar voor Urologie in Nijmegen. Nadien zijn de andere universiteiten met regelmaat gevolgd. Al snel nadien immers werd Donker in Leiden benoemd (1965).

Bakker mocht zich de eerste hoogleraar Urologie noemen aan de Erasmus Universiteit in Rotterdam in 1968. Boer volgde in Groningen in 1969 en Scholtmeyer aan de Vrije Universiteit in Amsterdam eveneens in '69. Ten Cate werd de eerste hoogleraar Urologie aan de Gemeentelijke Universiteit van Amsterdam in 1970, en Utrecht volgde met Coolsaet in 1980. Maastricht sluit dus de rij in 1987, en als zodanig kan ik mij gevoeglijk de laatste van de eersten noemen, een pioniersrol dus.

Dejure betreft het een jeugdig medisch specialisme, pas 24 jaar jong. Defacto is de Nederlandse Urologie, gerekend naar menselijke maatstaven, echter al hoogbejaard. Ruim 80 jaar geleden, in 1906, werd H.J. Brongersma als priwaatdocent toegelaten tot de Gemeentelijke Universiteit van Amsterdam. Zijn openbare les: "De Urologie, zelfstandig deel der medische wetenschap", was als beginselverklaring moedig en mooi, maar in 1906 utopia, een wensdroom, geen werkelijkheid. In datzelfde jaar, 1906, liet in Parijs Gertrude Stein zich portretteren door haar vriend Pablo Picasso die toen in zijn kubistische periode was. Wederzijdse vrienden vonden het portret niet erg gelijken. "Dat komt nog wel" zei Picasso. Dat had Brongersma ook kunnen zeggen over de Urologie als zelfstandig medisch specialisme maar het heeft wel een halve eeuw geduurd voordat dit vak niet meer als onderdeel van de algemene chirurgie werd beschouwd, de heelkundige aspecten ervan geleidelijk naar de achtergrond waren gedrongen en ook bij chirurgen begrip voor de eigen identiteit van de Urologie was ontstaan.

Mijn zeer gewaardeerde en uitermate scherpzinnige leermeester in de Chirurgic, de Amsterdamse hoogleraar Boerema, kwam pas beginjaren zestig tot de slotsom dat de urologische mogelijkheden zo waren toegenomen dat een algemeen chirurg die grote variëteit van behandelingen niet meer allemaal kon beheersen. Hij stuurde Ten Cate op studiereis naar het buitenland en zorgde ervoor dat die in januari 1966 in Amsterdam tot lector in de Urologie werd benoemd. 
Dames en heren, hoewel de geschiedenis wan de L rologie een boeiend chapiter is. en ik geneigd zou zijn dit unr voor een goed deel te vullen over dat onderwerp. zall ik het hier toch bij laten, immers de meeste hoogleraren die mij voorgingen gawen reeds een uitgebreid resumé. Wel echter zult u begrijpen dat ik toch geprikkeld was tot enige uitwijding over de geschiedenis van de Nederlandse Urologie. immers niet alleen werd ik opgeleid door een groot deskundige op het gebied wan de geschiedenis van de Urologie. Prof. Moonen, tevens had ik het genoegen om jarenlang samen te werken met collega Schreinemachers die in 1983 ter gelegenheid van het 75 -jarig bestaan van de Nederlandse Vereniging voor Urologie een voortreffelijk en zeer lezenswaardig. overzicht gaf van de ontwikkeling van de Nederlandse Urologie.

Wellicht vraagt u zich af waarom ik mij geroepen heb gevoeld om deze functie te aanvaarden. Immers. reeds 20 jaar was ik naar volle tevredenheid werkzam in éen wan de grootste urologische maatschappen van het land in een ziekenhuis. met een uitstekende outillage. Het patientenaanbod was bijzonder groot en de behandeling van de individuele patient gaf mij een intense satisfactie.

Door met een enthousiaste maatschap samen te werken om te trachten de nicuwste mogelijkheden van de Urologie in praktijk te brengen opdat wij de patienten volgens de modernste inzichten adequaat konden behandelen en daarnaast dan nog een grote groep van jonge assistenten op te leiden tot moderne trologen, niet alleen in technisch opzicht maar ook in menselijk opzicht, ontstond cen dagvulling die welliswat bijzonder intensief was maar daarnaast ook rijk aan variatie en inhoud.

En vanuit die bijna ideale behandelingssituatie heb ik toch gek ozen voor deze huidige functie. Een functie waarvan je je kunt afvragen of die zo benijdenswaardig is. Immers, wanneer men zich afvraagt wat de moderne klinische hoogleraar te verwerken krijgt, dan lijkt dat een welhast onmogelijke opgave. Zeker voor iemand die nog zo aan het begin van zijn hooggeleerde carrière statat. Hij moet immers trachten een manager te zijn van zijn klinische afdeling binnen een groot academisch ziekenhuis met soms ingewikkelde relaties met Bestutr. Directie, aarpalende specialismen. en een budget watrvan verwacht wordt dat hij vandaar uit geavanceerde patientenzorg bekostigt evenals wetenschappelijk onderzoek. Hij moet relaties onderhouden met de universiteit con het onderwijs in zijn wakgebied op goede hoogte houden. Hij moet als het even kan een beminnelijk mens zijn die zeer zeker uitstekende relaties moet onderhouden met de samenleving. Hij moet goede en zakelijke contacten kunnen leggen tussen de industrie en zijn afdeling om de ontwikkeling van nieuwe apparatuur wellicht mogelijk te maken en discussies met hen kunnen voeren op hoog technisch en maatschappelijk niveau.

Een velvoud van functies die weliswaar gedelegeerd kunnen worden aan bekwame stafleden. secretaresses en zelfs tegenwoordig een beheerder die 
meedenk over de franciede problemalek mat wat to h he overzich over moet worden behouder. En dar lenstote alles voor een betoning die minder is dar datgene wat hu als pertere specialist pleegt te onwangen.

Het an woord op de wrakg wataron dan woch deze overstap wind w in de thel

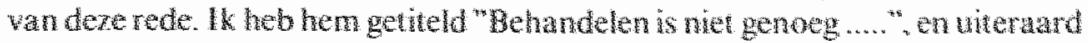
zult abgripen dat met het met ingevude ded wandeze zm word bedoeld dat patientenbehandeling een goede en uherst bevedigende werkatamheid is. maar dat er in die stwatie toch steeds wagen bliven over de bass van een zidke beld of vagen over mogelikheder wan neuwe herapentische toegangswegen. Om u duidelik te maken wat ik bedoel met behandelen is net genoeg ...." en wat daarnaast dan de imwling moet 20 n. special in deze universiteit. dat hoop ik in de resterende tijd atn we knnen thilegger.

Pratende over nieuwe ontwhkelingen in de Urotogie moet men enerzijds whisan van de basiskennis van vandaag en anderyds woorborduren op de verwachingen in de nabige toekomst. Hoe moeingh met name dat faatste is. de toekonstvoorspeling, noge nog weer een bliken utite recente a tschetdsrede die prof. Moonen in Nimegen hed en waarin his cen opsomming gal van het al of net uithomen wan zin verwachtingen, witgesproken in 2 in inaugurale rede 20 jarar tevoren.

Desondanks zal ik wij toch moten wagen aan uispraken over nieuwe wegen die wil zullen moeten instan. Inmers, aan de hand wan dat verwachingspatroon kan ook ten studie-opret worden gerealiseerd. Het gebied wan de Urohgie is echter zo veelomwattend dat het dudehik moet ajn dat niet in elke wiversiteitskiniek op alde fronten nieuwe wegen moeten worden ingeslagen. Er moet een dudelike keure worden gemakt en de unversiteiten onderling moeten gode contacten ond thotden om te weten welke niwa richtingen zif als sudie-onderwerp hebben gekozen. Indien een tweat klmeken dereffo wegripn ingestagen is owerleg en samenwerk mgeen absolum gebod. Heden ten dage kan men zells verder gaan en bliken samenwerkingsverbanden met buitenlandse klinieken zeer effectief te kunnen zijon.

L.atat ik u in eerste instantic a angeven over welke werkterreinen de Urologic zijn aandacht verdeelt en $u$ dan nader in enkele detalls inlichten over de huidige stand van zaken en de niewwe ontwikkelingen, mot name in Maastricht.

Met u wil ik praten over de 5 hooldgebieden van de Urologie:

1. de nefrolithiasis

2. de oncologie

3. de neuro-urologie

4. urologie bij kinderen

5. de mannelijke infertiliteit en impotentie 


\section{De nefrolithiasis - het niersteenlijden.}

Naturulik is de niersteen het meest klassieke werkterrein van de uroloog. Dearmee wordt hij valk vereenzelwigd. Was het in de oud heid de blassteen die de uroloog als zijn werkterrein had, door de verandering van onze eetgewoonten met name op basis van de stijging van de welvaart is de blaassteen wit het bevolkingsgebied van de welvarende landen verdwenen en is daarvoor de niersteen in de plaats gekomen. Dat welvaart en nierstenen een duidelijke relatie hebben blijkt uit een recente statistiek waarbij de hoogte van het inkomen (en daarmee de hoeveelheid eiwitgebruik) direct gerelateerd kon worden aan de frequentie van nierstenen.

Het fantastische technische geweld dat de laatste 10 à 15 jaar over de ontwikkelde westerse landen theenwalst en ons leven op vrijwel alle terreinen drastisch is gaan beinvloeden heeft ook de niersteen niet ongemoeid gelaten. Vanaf het begin van deze eeuw tot ongeveer 5 jaar geleden werden nierstenen op klassieke wijze operatiel verwijderd. Toen begon de eerste drastische verandering door de invoering van de zogenaamde percutane methoden. Daarbij werd het nierbekken aangeprikt, het prikkanaaltje opgerekt totdat er en buis doorheen kon, en vervolgens werd de steen in het nierbekken door trilsondes via deze buis kapotgemaakt en uitgespoeld, of met paktangetjes eenvoudigweg verwijderd. Voor de patient was dit een aanzienlijke verbetering door verkorting van de tijd in het ziekenhuis en evident minder lasten na de operatie. Voor de gemeenschap was het een aanwinst omdat het economisch veel minder belastend was. Maar ook deze revolutionaire verandering is alweer op de achtergrond geraakt. Eenieder van u weet dat de uitwendige niersteenvergruizer, d.m.v. schokgolven buiten het lichaam, de steen tot pulver verschokt waarna het gruis kan worden uitgespoeld en uitgeplast. Nadat het oorspronkelijk concept van deze therapie in Duitsland ongeveer 12 jaar geleden was ontwikkeld en tot een bruikbare machine werd geproduceerd, bleek dat deze behandelingsmethode in de aanvang bijzonder kostbaar was door de hoge aanschalkosten van de apparatuur. Hoewel eenieder inzag dat dit de ideale therapie van de toekomst was werd de aanschal van een niersteenvergruizer een politickespeelbal. De vraag daarbij werd wie deze ideale therapie in huis mocht hebben. Rotterdam ging door een voortvarend management met de eer strijken. Kort daarna werd het toch wel duidelijk dat ook op andere plaatsen in Nederland een dergelijke steenvergruizer moest worden geplaatst om aan de vraag te kunnen voldoen. Gelukkigzijn er immiddels apparaten ontwikkeld van de $2 \mathrm{e}$ en $3 \mathrm{e}$ generatie die veel minder kostbaar zijn geworden. De meeste universiteitsklimieken in Nederland hebben zich inmiddels verzekerd van een dergelijke machine en het verheugt mij bijzonder om te melden dat ook het Academisch Ziekenhuis Maastricht inmiddels over een dergelijke steenvergruizer gaat beschikken. Met behulp van een even ingenieuze als eenvoudige machine ontwikkeld door de firma Direx in Israël hopen wij aan te kunnen 
tonen dat het tijdperk van een goedkope en effectieve steenvergruizing nu is aangebroken. De discussie over het gewenste aantal machines in Nederland zal mede beinvloed worden door de snelle on wikkeling van dergelijke goedkope en eventueel verplaatsbare machines waardoor meendere ziekenhuizen tén apparaat kunnen delen. Pogingen om dit centraal vamuit regeringskringen te regelen worden momenteel doorkruist door particulier initiatief van ziekenhuisdirecties samen met hun urologen, zodat het spel van vraag en aanbod momenteel in wolle gang is. Als de technische ont wik keling hiermee gelijke tred houdt. resulteert dat in goedkope en handzame machines, waarbij het voor veel ziekenhuizen rendabel wordt om de machine zelf taan teschaffen. Adviezen van regeringszijde over het a antal benodigde vergruizers in Nederland zijn dan niet meer nodig.

Met het bezit van een eigen machine ben ik bijzonder gelukkig omdat het niet alleen om de behandeling van de patient gaat, maar ook on wetenschappelijk onderzoek bij een behandelingsmethode die nog zo bijzonder neuw is. Vaak immers zijn de juichkreten van het succes bij eerste behandelingen enorm groot en komen pas na jaren de berwaren respectievelijk complicaties.

Ik acht het dan ook als een bijzondere laak om de wetenschappelijke achtergronden bij de steenvergruizing nader te onderzoeken. Daarnaast komt dan nog het belangrijke punt van de metafylaxe d. w.z. het verder voorkomen van stenen bij iemand die eenmaal patient is. Wanneer de niersteenpatienten niet meer in ons ziekenhuis zouden worden behandeld zou ook de kennis over al deze belangrijke factoren verloren zijn gegaan. Wij zullen er nu een duidelijk studieprogramma van maken en, zoals dat past in de moderne tijd, dit volgens een volledig gecomputeriseerd programma onderzoken en afwerken. 


\section{De oncologie}

De tumoren van de verschillende onderdelen van de tractus urogenitalis bezorgen ons veel probiemen zolang er geen aldoende therapie tegen kankerprocessen is gevonden. Gelukkig is de meest voorkomende tumor bij de Urologie een zeer goedaardige nl. de prostaathypertrofie. Tot dusverre is deze alleen operatief te behandelen. De laatste maanden laait weer de belangstelling op om wellicht medicamenteus de groei te kunnen remmen.

Middels geavanceerde urodynamische meetapparatur hopen wij mee te werken an het onderzoek naar deze hypothese.

De komende jaren zal kanker in het algemeen toenemen uitsluitend als gevolg van de (dubbele) vergrijzing van de bevolking. Volgens een recent rapport van een scenariocommissie bedraggt de toename van het aantal nieuwe patiẻnten cat. $1,5 \%$ per jaar bij een gelijkblijvende incidentie. Verwacht wordt een toename van ca. 48.000 patienten in 1985 tot 60.000 in het jaar 2000 .

De gezwellen warmee de uroloog krijgt te maken zullen onder dezelfde ontwikkelingen vallen.

In het algelopen decennium is er op het gebied van de kankerprocessen binnen de Urologie én grote triomf geboekt, te weten het testiscarcinoom. Maar algezien van deze groep zullen wij toch nog steeds moeten leven met een deel dat inoperabel blijkt te zijn, en zodra een proces niet meer met het mes kan worden behandeld zijn de alternatieve methoden $z$ oals radiatie en chemotherapie meestal geen definitieve oplossing.

Toch is er ook voor de categorie patienten die niet meer curatief zijn te helpen de laatste tien jaar een duidelijke verandering gekomen. Ik praat nu over de kwaliteit van leven. Verbetering van de kwaliteit van leven geldt niet alleen voor de niet meer te helpen patient, maar ook voor de patient die nog wel curatieve therapie kan krijgen maar waarbij de therapie soms zeer ingrijpend is voor de kwaliteit van het leven wan de patient. Zo zeer komt deze factor de laatste jaren nu naar voren, dat vrijwel geen enkele nieuwe kankerstudie meer wordt opgezet zonder dat er rekening wordt gehouden met de factor kwaliteit van het leven.

Een aantal groepen van zeer georganiseerde onderzokers heeft zich gevormd en waarschijnlijk is de EORTC (European Organisation for Research and Treatment of Cancer), waarbij zeer vele Europese specialisten samenwerken. cen van de best georganiseerde instellingen ter wereld op dit gebied. ledere uroloog zou het zich derhalve tot een eer moeten strekken om hieraan mee te werken. Toch zijn er nog velen die hiervan afzien. vooral vanwege de zeer strenge discipline en een te grote hoeveel heid werk.

Hulp met datamanagement is een eerste vereiste om steeds meer urologen over de brug te halen. Gelukkig steekt hierbij de Nederlandse regering de helpende 
hand toe, want er zijn de laatste jaren integrale kankercentra gevormd, verspreid over het land, die behulpzaam zijn bij de documentatie van goed opgezette protocollen. Ook hier in Limburg is het I.K.L. (Integraal Kankercentrum Limburg) van start gegaan. Ik reken het tot een belangrijke taak om de daarin participerende urologen aan te zetten tot enthousiaste medewerking voor goede studies. Dat immers is momenteel ến van de mogelijkheden om de nog steeds toch betrekkelijk droevige behandelingsresultaten van kanker te verbeteren.

Overigens vraagt ook de farmaceutische industrie meer en mer onze aandacht voor vaak zeer fundamentele studies. Het voordeel van de participatie met de industrie is vaak de financièle armslag om $\mathrm{kwalitatief}$ goede studies te verrichten.

Een intensieve wisselwerking met de industrie op dit niveau vraagt een goed gedisciplineerde onderzoeksgroep van de universiteit: een kwalificatie die wij hopen te verwezenlijken.

Toch bligft het de vaag of de gekozen richting van cytostatische therapie wel uiteindelijk het antwoord zal brengen op het kankervragastuk. De locale doding van de kankercel is immers een secundaire therapie. Van alle vormen van therapie van kanker die wij heden ten dage kennen, te weten operatieve therapie, radiotherapie en chemotherapie, moet eerst het proces zich tot volle bloei ontwikkelen alvorens we enige therapie kunnen aanvangen. Nee, veel meer zal de ontwikkeling in de toekomst toch zijn dat de cytogenetica en de moleculaire genetica in een vroeg stadium reeds een betrouwbare voorspelling kunnen doen over de prognose. Dit betekent dat bij de kenze van de therapie met die bevindingen meer en meer rekening zal worden gehouden. De komende tien jaar zullen wij ons toch nog steeds moeten richten op de ons nu bekende therapieèn.

\section{De testistumor}

Over dit paradepaardje van de Urologie kan ik slechts melden dat ik bijzonder verheugd ben dat de huidige mogelijk heden met chemotherapie geleid hebben tot overlevingspercentages van $95 \%$ en meer. Het succes van de behandeling zullen wij nu meestal moeten overlaten aan de oncoloog.

$\| \mathrm{k}$ heb de tijd nog meegemaakt dat jonge mannen, want die zijn het meest behept met testistumoren, die kort tevoren jong en sterk waren in snel tempo afgleden naar de cachexie en de dood.

Om machteloos te moeten toezien hoe de vader van een jong gezin snel naar de dood werd geleid, heeft mij destijds bijzonder aangegrepen. Heden ten dage is de belangrijkste taak voor de Urologie om aan de huisartsen aan te geven hoe verraderlijk de testistumor zich nog kan presenteren. Wanneer hij echter maar in een vroeg stadium bij ons wordt ingeleverd is in bijna $100 \%$ van de gevallen een volledige genezing te bereiken. 
Dames en heren, de oncologie is een ongemeen boeiend wetenschappelijk onderwerp. Om mee te doen aan de basale research is een ongelooflike uitdaging. maar daamaast een bijzonder geldverslindend onderwerp dat de opzet vergt van uitgebreide laboratoria met bijzonder ingewikkeld instrumentarium voor de bepaling van steeds meer chemische en enzymatische onderdelen van het proces. Gezien de grote achterstand die Maastricht in urologisch opricht heeft op andere klinieken in het land en à fortiori de grote oncologische internationale klinieken ben ik niet meer van plan de urologische oncologie in al zijn grootsheid als wetenschap te introduceren in Maastricht. Wel echter zullen wij trachten via ến poot van het onderzoeksgedeelte, te weten de cylogenetica. ons steentje bij te dragen samen met de deskundigen die Maastricht reeds in zijn midden heeft. 


\section{De neuro-urologie}

Hiermee bedoel ik alle stoomissen die optreden met de mictie en daarbij dan natuurlijk ook de urine-incontinentie. Op de polikliniek ziet de uroloog percentsgewijze verreweg het meest patienten met klachten over de mictie. hetzij dat deze te frequent of te langzaam $\mathrm{kom} t$, damwel in het geheel niet of veel te gemakkelijk. Alle varianten zijn mogetijk. Met de toename van de vergrijzing van de bevolking is alleen maar te verwachten dat dit pereentage nog zeer sterk toeneernt. Bovendien worden patienten met aangeboren zenuwstoornissen resp. verworven zenuwstoornissen in veel gevallen in leven gehouden rodat ook de kwaliteit van het leven een duidelijke rol gaal spelen en daarbij de mictie vaak een eminente plaats inneemt.

Bemoeienis met de zeer grote groep van patienten die mictiestoormissen hebben behoort uiteraard geheel tot het vakgebied van de uroloog, maar het is verwonderlijk dat deze belangstelling pas sinds zo korte tijd in optima forma aanwezig is.

In ons land was het Ausems, uroloog in het Annadal Ziekenhuis in Matastricht. die de aandacht vestigde op het functieonderzoek van de blaas. In 1957 promoveerde hij cum laude op cen drukmetingsonderzoek wairbij hij nog gebruik maakte van een zeer simpele 1-kanaals schrijver. De conclusies die hij toen wist te trekken uit zo weinig gegevens vervullen ons nu nog steeds met bewondering. Internationaal kwam het functieonderzoek geleidelijk aan op gang en in 1969 werd het eerste urodynamische congres in Aken georganiseerd. Op dat congres theerste een echte pioniersgeest.

In de jaren '70 heeft het functieonderzoek een vaste plats gekregen in het onderzoekareaal van de uroloog en wij leerden dat er emstige innervatiestoornissen konden zijn met bijzonder hoge drukken die daardoor de afvloed van de nieren belemmerden en derhalve een direct levensgevaar betekenden. Toch was zelfs in de jaren ' 70 de exacte a natomie en fysiologie van de blaas nog steeds niet geheel bekend. Het moet ons met enige trots vervullen dat Donker één van de eersten was die angaf hoe nu eigenlijk de innervatie van de blaashals verliep. althans wat de verdeling betreft van parasympatische en sympatische zenuwvezels. En zo zijn wij geleidelijk toegek omen aan geavanceerd en gecomputeriseerd onderzoekmateriaal met tegenwoordig well acht schrijvers die verschillende drukmetingen tegelijkertijd coördineren. Daardoor ook is nu een volwassen functieafdeling op de Urologie een niet meer weg te denken onderdeel van het poliklinisch gebeuren. Het verheugt mij dan ook dat in mijn nieuwe situatie in de oud bouw reeds enigszins is rekening gehouden met cen functieafdeling en dat in de nieuwbouw een volwaardige functieafdeling is ingepland.

Om patienten met zenuwstoornissen van de blaas le kunnen helpen is de eerste voorwaarde waaraan moet worden voldaan dat de anatomie en fysiologie goed 
bekend is. Daar hebben we nu. zoals ik zojuist uiteenzette enig inzicht in. Maar hoe stat het eigenlijk met ons therapeutisch kunnen? Die heft ook een moeizame ontwikkeling doorge makt.

Medicamenteus sijn het sympatische en parasympatische zenuwstelsel weliswaar te beinvloeden. matar het probleem is toch dat de dosering van een medicament vaak zo bijzonder hoog moet zijn dat de bijwerkingen dientengevolge ook groot zijn. Medicamenteus hebben wij dus weliswaar enkele hulpmiddelen maar effectief is het toch nog allerminst.

Bij sommige mensen zullen wij het euvel niel moeten zoeken in hun perifere zenuwen mal meer in hun centrale zenuwstelsel. Foute mictiegewoonten ontstaan ongetwiffeld op basis van stresssituaties. Klassiek immers is toch de uits praak dat de blaass de spiegel van de ziel is. Samenwerking daarom met de psycholoog lijkt voor deze groep patienten de meest aangewezen weg. Nadat wij samen met hem de basis van de problematiek hebben blootgelegd, zullen wij de patient moeten heropvoeden wat betreft zijn blaasfunctie en mictiegewoonten. Een dergelijk proces met de naam bio-feedback is in ontwikkeling en wij hopen daarbij ons aandeel te kunnen leveren. Daarnaast heeft onget wijfeld het hormonale en enzymatische systeem een verstorend effect op de zenuwwerking. Voor die patienten tenslotte waar bij de perifere zenuwbanen vanaf het ruggemerg zijn gestoord hebben recente onderzoekingen in Londen en San Francisco aangetoond dat directe neurostimulatie van de voor-en achterwortels komende tuit het ruggemerg tot frappante verbeteringen van de innervatie kunnen leiden.

Dames en heren, in slechts enkele zinnen heb ik u trachten uit te leggen hoe ingewikkeld en hoe veelomvattend het terrein is van de mictiestoornissen en incontinentieproblematiek. In het begin van mijn betoog zette ik al uiteen dat het nodig is om keuzes te maken wat betreft het zwaartepunt van de behandeling. Gezien mijn jarenlange ervaringen met patienten met deze problematiek en met name ook de intense belangstelling voor alle nieuwe ontwikkelingen die ik tot dusverre op de voet heb gevolgd, heb ik voor Maastricht als zwartepunt deze problematiek gekozen. Een bijzondere taak ligt er mijns inziens woor ons, walarbij de hulp van zeer velen en met name ook van neuro-fysiologen en neurobiologen hard nodig is on een verdere tip wan dege sluier op te tillen.

Samenwerking ook met de gynaecoloog omdat de mictieproblematiek vaak zo verwewen is met hormonale en anatomische problemen van het vrouwelijk geslachtsmechanisme.

De voorutzichten lijken veelbelovend zowel op diagnostisch als op therapeutisch terrein. Graag had ik dit gehele uur gevuld met de vele bijzondere aspecten van dit onderwerp, maar ik meende dat het niet goed zou zijn om mij zo monomaan aan u te presenteren. De Urologie in zijn volle omvang zullen wij bedrijven maar dit gedeette zal onze bijzondere wetenschappelijke belangstelling hebben. 


\section{De kinderurologie}

Hoewell de laatste tijd het aantal kindergeboorten per jaar mag zijn afgenomen en daarmee uiteraard ook de aangeboren aandoeningen van de urinewegen, is de ernst ervan niet verminderd. Doordat niet meer ledere urolloog 20 'n grote schare aan kinderen ziet, gaat langzamerhand de evvaring op dat tertein ontbreken en wordt centralisatie van de grote problematiek geboden. Binnen de Nederlandse Urologie is de kinderuroloog dan ook de eerste die zich als separate deelspecialist heeft gevestigd. Voor de regio Limburg is een kinderurologisch centrum zeker aangewezen mede gezien de afstanden naar de rest van het land. 


\section{De infertiliteit en de impotentie van de man}

Hoewel het infertiele echtpat gebruikeligk het eerst bij de gynaecoloog terecht komt is toch de tijd al lang voorbij dat de klassieke vinger wordt gewezen naar de vrouw wanneer een echtpaar infertiel bijkt te zijn. Immers inmiddels weten wij goed dat de infertiliteit eenvoldigweg fifty-fifty over het paar is verdeeld. Een gotde samenwerking met de gynaecoloog lijkt dan ook het meest voor de hand te liggen, en wordt tegenwoordig ook in de meeste klinieken gerealiseerd.

Naast de vele ontwikkelingen die rich hebben voorgedaan op deelgebieden in de urologie, heeft men zich de lartste jaren ook ingespannen meer inzicht te krijgen in de mannelijke infertiliteit. Helaas heeft dit tot dusver nog niet geleid tot nieuwe geavanceerde behandelingen. Wel kunnen wij nu aan de hand van vele gegevens wit het sperma en het bloed een vrij duidelijke prognose geven aan het echtpaat". Wanneer die prognose ten ammien van de mannelijke infertiliteit ongunstig is zijn de therapeutische mogelijk heden evenwel nog gering.

Opmerkeligk anders is het verloop van onze inzichten over een klein onderdeel van ons vak dat weliswaar geen belang heeft bij de vitale functies van de mens in de zin van het direet in leven blijwen. maar daamaast toch de kwaliteit wan hel leven reker mede bepaatt. Ik doel daarmee op de potentic van de man.

In mijn opleidingstijd en zeker ook de eerste tien jaar madien was het onderwerp zeer zelden reden voor enige publicatie in onze wetenschappelijke tijdschriften. Het was immers bekend dat de man tot op hogere leefijd viriel kan zijn, en mannen die hieraan niet beantwoordden hadden watschijwijk erectiestoornissen op grond van psychische remmingen.

En dan komt ongeveer 10 jaar geleden het eerste inzicht dat toch wellicht de impotentie niet altijd alleen psychogeen bepaald is maar dat wel degelijk somatische oorzaken hieraan ten grondslag kunnen liggen, m. $n$. wat betreft de toestand van de bloedvaten. Ook begint langzaam enig anatomisch inzicht te ontstaan over het mechanisme van de erectie.

In cen aantal groteseries goed nagekeken mannen met erectiestoornissen blijkt dan. dat ongeveer $50 \%$ inderdaad psychogene remmingen heef. maar anderyijds $50 \%$ hele duidelijke somatische afwijkingen. En als dan vervolgens de anatomie en fysiologie van het gehele erectiegebeuren duidelijk wordt, volgt daaruit ook medicamenteuze en andere therapie. En zo zijn wij dan heden ton dage in een lase gekomen dat sommige behandelingscentra voor impotente mannen zells claimen dat $100 \%$ van alle mannen is te helpen. Onder helpen moet u dar niet verstan dat er een volledige genezing is ontstaan, maar dat er hulpmiddelen te baat kunnen worden genomen, waardoor de problematiek althans wordt opgelost. Over alle technische details zal ik nu niet uitwijen mara laat ik volstaan met te zeggen dai het scala van behandelingen inmidcles 
een zeer wijde is reikende van medicamenteuze therapie via locale injecties met middelen, langs operatieve correcties van een zgn veneus lek naar tenslotte de implantatie van semi-rigide en opblaasbare penisprotheses. De hulp van de psycholoog tenslotte is voor een klein percentage van de patienten nog weggelegd, maar het valt mij steeds op dat de patient met evidente psychogene remmingen er zeer weinig voor voelt om dit te laten titzoeken door de psycholoog omdat de therapeutische verwachtingen niet hoog liggen. Liever kiezen zij voor een directe zelfbehandeling met bijvoorbeeld papaverine. Tenslotte valt dan nog te melden dat een deel van de patienten de problematiek zell kan oplossen eenvoudigweg door het roken te staken.

Studies hebben immers aangetoond dat zware rokers percent gewigs veel vaker impotentieklachten hebben dan mannen die niet roken. 
Op deze vijf deelgebieden ben ik nader met u ingegaan. Voors moet mij nog een ontboezeming van het hart. Terwijl immers de buitenstaander tegen de urologie aankikt als een zgn. klein specialisme afstammend tit de chirurgie. moge het na opsomming van de bovengenoemde 5 deelgebicden duidelijk zijn dal onze belangstelling zich moet uitstrekken over grote delen van de geneeskunde. De mythe dat Urologie "zo'n aardig snijdend vak" is blijft echter een härdnek kig bestaan leiden. Dat is uiteraard ntet zo werwonderlijk wanneer men althans uitgaat van de detinitie wat een mythe is: "De mythos is het geldig blijvende verhaal dal kenmerkend is voor een volkssoort". Deze definitie geeft prof. De Boer, en dominee Simoons noemt de mythe "de traditie van primitievere wijsheid die het leven beschermt". De mythos wan dat kleine wak hoop ik te doorbreken, de logos van elke dag is wel anders!

Immers, bij de nierstenen zullen wij inzicht moeten hebben over het metabolisme van de kalkstofwisseling en andere stoffen die steenvorming verooryaken. Bij de oncologie zullen wij moeten ingaan op cytostatische mogelijkheden naast de klassieke behandelingsmethoden van operatie en radiotherapie. Ook de immunologie en genetica spelen daarbij een rol. Bij de neuro-urologie zullen wij een intense kennis moeten ontwikkelen van het autonome-zenuwstelset en alle pharmacologische mogelijkheden die er zijn om dit te beinvloeden. Bij de kinderurologie moet onze embryologische kennis inzicht geven aan correctiemogelijkheden. Bij de inlertiliteit en impotentie komt de kennis van het hormonale systeem als onontbeerlijk op ons af. Wanneer ik u in vogelvlucht een zo groot scala van de geneeskunde noem warmee de Urologic te maken heeft zal het u duidelijk zijn dat geen enkele uroloog al deze gebieden in zijn volle omvang kan beheersen, zodat hij zich zal moeten beperken tot een grote kennis op eén bepaald deelgebied en dat samenwerking met een groot scala van nevenspecialisten onontbeerlijk is.

Het moge u zijn opgevallen dat ik in het rijte van de deelgebieden de urineweginfectie niet als apari deelgebied heb genoemd. Toch is het eenieder witeraard duidelijk dat het infect van de urinewegen een dagelijks weerkerende problematiek is, maar het infect is vrijwel nooit als een zelfstandige identiteit te zien.

Hot is de takk van de uroloog om de oorzak van de infectic naderante geven cn dere zal vaak gerocht moeten worden in één van de bovengenoemde doelgebieden.

Dames en lneren, nadat ik u ro in vogelvlucht heb meegenomen door recente ontwik kelingen binnen de Urologie en daarna, naar ik hoop. heb titeen gezed wat er zoal aan wetenschappelijk onderzoek moet gebeuren kan ik het toch niet laten u crop te wijzen dat door het grote technische geweld waardoor ons vak in non stroomversnelling is gekomen er toch én lactor niet over het hoofd gezien mag worden en wel de persoonlijke aandacht van de individuele patient. Want nog altijd is het zo dat we weliswar per ziektebeeld bepaalde therapieen 
hebben te bieden maar dat deze altijd gerelateerd moeten worden aan de mogelijkheden en de wensen van het individu. Onze taak als voorlichter an de patient is met het toenemen van de mogelijkheden ook groter geworden. Natunirlijk weten we allemaal dat de patient weliswar zell ook mondiger is geworden. maar wat moet hij als leck toch kiezen uit dat scala van nieuwe technische mogelijkheden? Omdat het onze taak is om heel zorgvuldig uit te leggen wat er aan de hand is enerzijds en wat de therapeutische mogelijkheden zijn anderzijds. zullen wij in de toekomst er rekening mee moeten houden dat wij per individuele patient meer tijd en aandacht moeten besteden aan die voorlichting. Zell betrek ik vrijwel altijd de familie in het gesprek temeen wanneer het om moeilijke beslissingen gaat. Moeilijk vooral ook kunnen de beslissingen worden bij het ouder worden van de mens en het dilemma dat wij daarbij ontmoeten, te weten waar zijn de grenzen van mijn technisch kunnen. waar moet ik ophouden met puur behandelen en waar moet nog slechts een helpende hand worden geboden"? Behandelen is niet genoeg .... heb ik ook altijd in de context geplatst van: Behandelen is ook medeleven.

Binnen onze afdeling hoop ik dan ook dat ik steeds de nadruk kan blijven leggen op de bijzondere band die er moet zijn tussen de patient en de dokter die hem begeleidt vana de eerste dag van zijn ziek-zijn tot hopelijk zijn volledige genezing. In universiteitsklinieken dreigt nog wel eens een versnippering van de werkzaamheden zodat de patient steeds andere dokters tegenover zich krijgt met het evidente gevaar van steeds andere uitleg over hetzeltde probleem. Dat moet hem wel onzeker maken en juist het verschaffen van zekerheid. zelfs bij aandoemingen met een sombere prognose kan de patient door hele moeilije vaarwaters heen leiden.

Gelukkig is de stal van de Urologie in ons ziekenhuis nu nog maar een betrekkelijk kleine groep zodat het overzicht en de individuele aandacht mogelijk moet blijven maar naar ik hoop zullen wij in de tockomst groeien. Debruyne in zijn inaugurale rede in Nijmegen vroeg zich in 1982 af of wij. de Urologie. wellicht te klem zijn voor grote dromen. Zelf gaf hij het antwoord ook al en ik kan dat slechts bevestigen. Niet alleen zijn er grote dromen bij de Urologie, maar zij zullen ook verwezenlijkt worden. Daar ben ik van overtuigd. 


\section{Onderwijs}

Dames en heren, studenten van deze medische faculteit, de hoofdtaak van de medische faculteit in Maastricht is gericht op de huisartsengeneeskunde en dus om te trachten $k$ walitatief goede huisartsen af te leveren. Hoewel u zich dat op dit moment nog niet bewust bent kan ik u nu reeds zeggen dat de Urologie een belangrijk onderdeel van uw werkxaamheden zal omvatten. Daarom heef het mij bijzonder verbaasd dat in uw leerpakket de Urologie nog zo schaars is vertegenwoordigd. U zal zich er op moeten voorbereiden dat ik daar iets aan wens te veranderen. Welis wat levert dat woor u weer een uitbreiding van uw studiepakket op, maar het zal u de voldoening geven om patienten binnen mijn vakgebied zelf ook vaak tot volle tevredenheid te kunnen behandelen in plaats van hen door te sturen naar de specialist.

Assistenten in opleiding, met $u$ wil ik niet praten over de technische aspecten van het vak want dat doen we de hele dag al. Eerder wil ik het hebben over uw toekomstperspectieven in de maatschappij. Binnen de Nederlandse Vereniging voor Urologie hebben velen al jaren met noeste arbeid getracht om de balans te houden tussen de daadwerkelijke behoefte aan urologen en het aantal op te leiden assistenten. Dankzij de inspanning van vele urologen kan ik u nu een redelijk toekomstperspectief bieden. Als goed opgeleid uroloog zult u met voldoening uw werk kunnen doen, met name in de directe patientenzorg. Wel wil ik er voor de nabije toekomst op wijzen dat wij toch behoefte hebben aan een categorie mensen die zich een leven lang binnen de universiteit wijden aan wetenschappelijk onderzoek.

Ten opzichte van het buitenland hebben wij nog maar een hele prille status van wetenschapsland. Met slechts enkele kleine onderwerpen kunnen wij internationaal meetellen. Het is onze taak, meen ik, om nu een generatie urologen op te leiden met zuiver wetenschappelijke belangstelling en het is de taak van de universiteiten om voldoende middelen te verschaffen om die wetenschappelijke arbeid ook te kunnen volbrengen.

\section{De niet-universitaire klinieken:}

Om goede urologen op te leiden heeft de N.V.V.U. (Ned. Ver. voor Urologie) als eerste hier in Nederland in 1973 aan het Centraal College een schema gepresenteerd van gescheiden opleiding, te weten een deel universitaire opleiding. waarbij de nadruk wordt gelegd op de basale kennis en wetenschappelijke belangstelling, en een niet-universitair deel in grote perifere klinieken, waar de nadruk wordt gelegd op practische handvaardigheid. Op die manier hopen wij volwaardige urologen af te leveren, die vanaf dat punt hun keuze kunnen maken van practische Urologie of een wetenschappelijke carrière binnen de universiteit.

Goede samenwerking binnen het cluster van de 2 opleidingsklinieken, de universiteit en periferie, is een dringende eis. Samen met de urologen in Heerlen hopen wij een goede opleidingseenheid op te bouwen. 


\section{Dankwoorden}

Dames en heren, aldus bijna aan thet einde gekomen van mijn rede, en ter afsluiting van deze plechtige bijeenkomst wil ik enkele persoonlijke woorden uitspreken. Woorden voornamelijk van dank aan diegenen die hebben bijgedragen tot het feit dat ik hier vandaag voor u sta.

Heren leden van het College van Bestuurvan deze Universiteit, het was niet uw schuld dat de leerstoel voor Urologie zolang onbezet bleef. Samen met het Academisch Ziekenhuis heeft u voldoende moeite gedaan om capabele mensen te vinden. Doordat vrijwel alle Nederlandse urologen zo veilig zijn ingebed in hun goedlopende perifere praktijken en de universiteiten nog geen Nederlanders van voldoende kaliber hebben afgeleverd voor een dergelijke academische positie, had $u$ het moeilijk. I $\mathrm{k}$ waardeer hei dat $u$ in $z$ 'n vroeg stadium van de zoekacties niet naar het buitenland bent uitgeweken. I mmers, hoe zeer wij ook de hulp van buitenlandse urologen waarderen, ergens moet er toch een basis gelegd worden woor een hechte Nederlandse universitaire Urologis. I $k$ dank u dat $u$ dat vertrouwen in mij heeft gesteld en ik hoop het waar te mogen maken.

Leden van Bestuar en Directie van het Academisch Ziekenhuis Maastricht. Dat ik voor een deel in uw dienst ben demonstreert nog altijd de nadruk die moet worden gelegd op de patientenzorg. Door de open wijze watarmee onze gesprekken werden gevoerd om tot een gezamenlijk inzicht te komen hoe de afdoling Urologie zich uiteindelijk zou profileren, werd mujn enthousiasme om hier te komen werken eerst goed gewekt. I k had steeds het gevoel dat u mij graag bij de ploeg wilde hebben, hetgeen mijn beslissing vergemakkelijkte. Mijn wensen en verlangens alvorens van beide kanten het ja-woord uit te spreken heeft $u$ steeds met belangstelling aangehoord en waar mogelijk ook in redelijkheid geëffectueerd. I $\mathrm{k}$ dank $u$ in het gestelde vertrouwen en hoop met u een geavanceerde afdeling Urologie op te bouwen.

Hooggeleerde Kootstra, Gouke.

ats voorzitter van de benoemingscommissie vond ik in jou een zeer ent housiaste pleitbezorger voor de Maastrichtse zaak. Aanvankelijk had ik enige bedenkingen tegen de komst hier naar toe, maar de hattelijke wijze watrop jij de zaken uiteenzette nam mijn twijfel weg. En toen we cenmaal voorzichtig in de richting van deye nieuwe haven voeren ont popte jij je als een zeer betrouwbare loods. Jij wees mij voorzichtigen rustig de klippen onder water en voer mij langzaam maar gedecideerd naar binnen. Door jouw steun wist ik dat ik cen juiste keuze had gemaakt. 
Hooggeleterde Moonen, Wim.

niet alleen leerde jij mij het vak, maar jij leerde mij ook dat het een voorrecht is om uroloog te mogen zijn. Vooral jouw intense belangstelling en medeleven met de patient maakte dat ik de zeer bijzondere rol die de patient in dit geheel speett op zign juiste waarde ging schatten. Daarna waren wij 15 jaar geassocieerd waarbij ik me verheugde samen met jou de afdeling Urologie in het Grootziekengasthuis in Den Bosch tot een moderne afdeling verder wit te bouwen. Ik prijs mij gelukkig dat ik zulke bijzondere mensen als Boerema in mijn chirurgische stadium en jij bij mijn binnenkomst in de Urologie tot mijn leetmeesters mocht rekenen.

Geleerde Schreinemachers, Smans en Hoekstra, Louis, Adriaan en Wytze. samen hebben wij in Den Boschen Oss én van de grootste opieidingspraktijken van het land mogen uitbowwen.

Door de ongelooflijke inzet van ieder van jullie bleef de maatschap samen met de assistenten tot én grote vriendenclub.

Zeergeleerde Ausems en geleerde Weil en Van de Beek, Max, Ernest en Kees. jullie hebben een zodanig goed gefundeerde basis gelegd voor de afdeling Urologie dat ik in een gespreid bedje stapte en mij kon beperken tot aanvullingen om te komen tot een academische afdeling. Wij mogen dan nog slechts aan het begin staan van deze jonge afdeling, ik heb echter alle vertrouwen dat wij deze zullen uitbouwen tot een waardig volwassen afdeling waarin alle facetten van de Urologie volledig tot hun recht zullen komen.

Max, jij hebt inmiddels de afdeling verlaten nadat je tot in je 65 -ste jaar je beste krachten gaf. Je hebt 30 jaar lang de afdeling geleid en $i k$ kan niet anders dan met grote bescheidenheid nu het roer van de afdeling van je overnemen.

Beste verpleegkundigen en ad ministratieve staf van de afdeling; Uw aandeel in de verzorging van de patient was en is niet alleen onontbeerlijk, maar ook met een hele diepe ondergrond. $U$ bent het immers, die het eerst met de patient in contact komt en hem ook de hele dag steeds weer ziet. Het vertrouwen van de patient in de behandeling zal voor een groot deel mede van u athangen. Een goede samenwerking tussen ons allen is dan ook een absolute noodzaak. Dat dit zal lukken heb ik de argelopen 7 maanden reeds ervaren en daarom zie ik ook met vertrouwen de toekomst samen met u tegemoet.

Mijn ouders en schoonouders dank ik voor alle kansen die zij ons in het verleden hebben geboden, leidende tot deze belangrijke stap.

Inge, Maarten, Justine en Diane, de prachtige tijd in Den Bosch en Vught hebben wij af gesloten, en ik ben ervan overtuigd dat er nu een nieuwe en andere periode in ons leven aanbreekt. 
Maarten, Justine en Diane, jullie ontwikkelen je tot zelfstandige en actieve studenten. I $k$ hoop dat de harmonische basis die we destijds gelegd hebben, er aanleiding toe zal zijn dat jullie ons in Maastricht ook steeds weer blijven verblijden met jullie komst.

Inge, in zijn algemeenheid mag het waar zijn dat niemand onmisbaar is maar als ik zeg dat ik niet zonder jou kan dan meen ik dat oprecht. Gedurende de afgelopen jaren remde jij mijn soms al te drieste plannen af door mij met simpele en zakelijke opmerkingen weer met beide benen op de begane grond te plaatsen. Maar tegelijkertijd steunde jij mij en hielp jij mij bij het verwezenlijken van hetgeen wel haalbaar en zinvol was. Wij gaan nu samen verder in Maastricht en ik verheug mij op een harmonieure tijdsverdeling tussen universiteit, ziekenhuis en eigen thuis.

Dames en heren, ik heb gezegd en dank u voor uw aandacht en geduld. 


\section{Literatuurlijst}

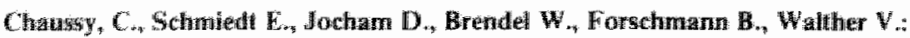

First chical experiences with extracomporally induced destruction of kidney stones by shock waves.

J. Urol. $127(1972): 417-420$

Chawssy $C_{*}$ Eissentuerger $F$. Wanner $K$ :

The use of shock wave for the destruction of renal calculi without direct contact

Urol. Res, 4 (1976): 181

Terpstra S., Postma Th.d.B.M.:

Scenario's voor de kankerbestrijding in Nedertand

Medisch contact $40(1987): 1267-1269$

Coebergh $\mathbb{H}_{2}$ W. W., Oosterom vam A.T, en Stater G.:

Scenaric's wan kankerbestrijding in Nederland $1985-2005$

Med. contact 39 (1987): 1229-1233

\section{Mander N.H.:}

Monocional antibediex: State of the art

J. Urol. 137 (1987): $603-612$

Juenemann K.P., Ilue T.G., Luo J.A., Benowitz N.L., Abozeid M., Tanagho E.A.: The efrect of cigarette smoking con penile erection

J. Urol $138(1987): 438-441$

\section{Wallsh P.C.. Donker P.J.:}

Impotence following radical prostatectomy: Insight into eteology and prevention

J. Urol. $128(1982): 492-497$

Thuiroff J.W., Baseed M.A., Schnidt R.A., Wiggin D.M., Tanagho E..A.:

Functional pattern of sacral root stimulation in dogs.

J. Urol. $127(1982): 1031-1033$

W.A. Moonen:

Ne Umquam pars pro toto.

Afscheidscollege Nijmegen 1985.

M. M. Ausem:

De cystometric.

Proefschrilt Leiden 1957.

Logos an Mythos,

Nederlands Gespreks Centrum, 1974.

\section{Comelis Verhoeven:}

Siril statan bij het water.

Uitg. van Spijk - Venlo, 1988

\section{C.M.l. Debruyne:}

Te klein voor grote dromen?

Iratugurale rede Nijmegen 1982. 